\title{
DESKRIPSI PENGEMBANGAN PADI LOKAL (Studi Kasus Padi Pandanwangi Cianjur)
}

\author{
Dika Supyandi $^{1}$, Yayat Sukayat ${ }^{2}$, Adi Nugraha ${ }^{3}$ \\ 1,2,3, Program Studi Agribisnis Departemen Sosial Ekonomi Pertanian \\ Fakultas Pertanian Universitas Padjadjaran \\ E-mail: dika_supyandi@yahoo.com
}

\begin{abstract}
ABSTRAK
Menghadapi era kompetitif saat ini, hanya mereka yang dinamis, responsif, inovatif dan kompetitif yang akan bertahan. Karena itu, idealnya daya saing harus didorong oleh inovasi dan kreativitas. Upaya paling mendasar untuk dapat bersaing adalah mengupayakan realisasi penggunaan sumber daya yang efisien. Ini berarti bahwa penggunaan sumber daya harus difokuskan untuk menghasilkan produk yang memberikan hasil terbaik, dalam arti menghasilkan jumlah produk yang optimal dan kualitas terbaik, dengan biaya serendah mungkin. Salah satu langkah yang dapat diambil untuk mendapatkan produk yang kompetitif adalah menghasilkan produk yang unik dan berbeda dari produk lainnya. Dalam keragaman kekayaan alam Indonesia, hal ini dapat dilakukan dengan memproduksi produkproduk lokal dengan keunggulan spesifik yang dimiliki. Kajian ini bertujuan untuk membentuk model pengembangan padi lokal (padi pandanwangi) yang adaptif terhadap berbagai perubahan, baik perubahan sosial, ekonomi maupun lingkungan.. Makalah ini mendeskripsikan kondisi obyektif, terutama terkait dengan potensi dan masalah dalam pengembangan beras pandanwangi saat ini dengan pendekatan soft system methodology. Juga diidentifikasi pengembangan sistem agribisnis untuk beras pandanwangi di lokasi penelitian, yang terkait dengan berbagai kelembagaan yang terlibat baik perangkat keras maupun lunak, serta para pelaku dan kegiatan dalam pengembangan beras pandanwangi.
\end{abstract}

Kata kunci: padi lokal, soft system methodology, Cianjur

\begin{abstract}
Facing the current competitive era, only those who are dynamic, responsive, innovative and competitive will survive. Therefore, competitiveness must ideally be driven by innovation and creativity. The most basic effort to be able to compete is to strive for the realization of efficient use of resources. This means that the use of resources must be focused on producing products that provide the best output, in the sense of producing the optimal quantity of products at the best quality, with the lowest possible cost. A step can be taken to obtain a competitive product is to produce a unique product that is distinctive, different from the others. In the diversity of Indonesia's natural wealth, it can be done by producing local products with specific advantages possessed. This study aims to form a model of local rice development that is adaptive to various changes, both social, economic and environmental. This paper aims to obtain a description of the objective conditions, especially related to the potential and problems in the development of Pandanwangi rice employing soft system methodology approach. In addition, it is also identified the development of agribusiness systems for pandanwangi rice at the research sites, related to various institutions involved, both hard and soft, the actors and activities in the development of pandanwangi rice.
\end{abstract}

Keywords : local rice, soft system methodology, Cianjur 


\section{PENDAHULUAN}

Menghadapi era persaingan dewasa ini, hanya mereka yang dinamis, responsif, inovatif dan kompetitif yang akan dapat bertahan. Oleh karenanya, kemampuan daya saing idealnya harus didorong oleh inovasi dan kreativitas. Upaya paling mendasar untuk mampu bersaing adalah dengan mengupayakan terwujudnya efisiensi pemanfaatan sumberdaya. Ini berarti penggunaan sumberdaya harus difokuskan untuk menghasilkan produk yang memberikan luaran terbaik, dalam arti menghasilkan kuantitas produk yang optimal dan berkualitas terbaik, dengan korbanan yang serendah mungkin. Salah satu langkah yang dapat dilakukan untuk memperoleh produk berdaya saing adalah menghasilkan produk unik yang memiliki kekhasan (distinctive), berbeda dengan produk lainnya. Dalam keragaman kekayaan alam Indonesia dapat dilakukan dengan menghasilkan produk bercita rasa lokal dengan keunggulan spesifik yang dimiliki.

Dalam sektor pertanian, kekhasan ini tercermin melalui indikasi geografis (IG). Sejumlah produk memperoleh perlindungan hukum IG dari pemerintah, diantaranya : Kopi Arabika Kintamani, Meubel Ukir Jepara, Mete Muna, Pala Tomandin Fakfak, Kayu Manis Koerintji, Lada Putih Muntok, Kopi Arabika Gayo, Tembakau Mole Sumedang, Susu Kuda Liar Sumbawa, Teh Java Preanger, Kangkung Lombok, Madu Sumbawa, Beras Adan Krayan, Kopi Arabika Flores Bajawa, Purwaceng Dieng, Vanili Kepulauan Alor, Kopi Arabika Kalosi Enrekang, Ubi Cilembu Sumedang, dan Salak Pondoh Sleman.

Padi lokal Indonesia juga menghadapi tantangan persaingan tersebut. Dengan volume impor yang pada waktu tertentu masih tinggi untuk komoditas beras medium, pemenuhan kebutuhan konsumsi dalam negeri saat ini dapat dipenuhi. Meski demikian, identifikasi dan pengembangan varietas padi lokal yang unggul harus terus diupayakan sehingga beras Indonesia memiliki daya saing yang "berbeda" saat berhadapan dengan produk dari negara pesaing lainnya.

Di Jawa Barat, salah satu varietas padi yang sudah sejak lama menjadi unggulan adalah varietas Pandanwangi Cianjur. Varietas ini juga sudah memperoleh perlindungan IG. Padi Pandanwangi mempunyai keunggulan dari segi aroma, rasa dan tekstur nasi yang pulen. Kekhasan yang dimiliki Pandanwangi tersebut membuat beras Pandanwangi bergengsi dan diminati masyarakat menengah ke atas meskipun harganya tinggi. Dinas Pertanian Kabupaten Cianjur menetapkan Pandanwangi sebagai komoditas unggul utama disamping tanaman palawija, sayuran, buah-buahan, dan tanaman hias (Podesta, 2009).

Perkembangan luas tanam dan produksi padi Pandanwangi dalam beberapa tahun terakhir terus mengalami kenaikan, sebagaimana dapat dilihat pada Tabel 1.

Tabel 1. Luas Tanam dan Produksi Padi Pandanwangi di Kabupaten Cianjur

\begin{tabular}{lcrr}
\hline No & Tahun & $\begin{array}{c}\text { Luas } \\
\text { Tanam } \\
\text { (ha) }\end{array}$ & \multicolumn{1}{c}{$\begin{array}{c}\text { Produksi } \\
\text { (ton) }\end{array}$} \\
\hline 1 & 2012 & 52 & 301,5 \\
2 & 2013 & 63 & 415,5 \\
3 & 2014 & 74 & 482,4 \\
4 & 2015 & 79 & 516,0 \\
& Total & 268 & $1.715,4$ \\
\cline { 2 - 4 } & Rata-rata & $15,12 \% /$ th & $41,19 \% /$ th \\
\multicolumn{3}{c}{ Pertumbuhan } \\
\hline
\end{tabular}

Sumber: Dinas Pertanian, Perkebunan, Pangan dan Hortikultura Kabupaten Cianjur (2016)

Terlihat bahwa sejak tahun 2012 hingga tahun 2015, terjadi kenaikan luas tanam rata-rata sebesar $15,12 \% /$ tahun, dan kenaikan produksi rata-rata sebesar 41,19 $\% /$ tahun. Hal ini memperlihatkan dari sisi produktivitas, padi Pandanwangi menunjukkan kecenderungan yang semakin meningkat. Daerah sentra 
produksi Pandanwangi terdapat di

sejumlah kecamatan di Kabupaten Cianjur, diantaranya di Kecamatan

Warungkondang, Cibeber, Cugenang, Cilaku, Cianjur, Gekbrong dan Campaka.

Di tengah fakta tingginya harga beras premium, khusus dan aromatik seperti varietas Pandanwangi, dalam perdagangan beras kemasan berlabel, informasi mutu beras yang tertera dalam kemasan belum sepenuhnya menunjukkan mutu beras. Label beras yang tertera dalam kemasan, terkadang tidak sesuai dengan isinya. Ada empat cara yang sering dilakukan di tingkat penggilingan maupun pedagang beras untuk memanipulasi mutu beras, yaitu: (a) pencampuran beras antar varietas maupun antar kualitas (pengoplosan); (b) reprosesing atau penyosohan ulang beras turun mutu; (c) penyemprotan senyawa aromatik/bahan pemutih dengan konsentrasi yang tidak terkontrol sehingga berbahaya bagi kesehatan; dan (d) label kemasan yang tidak sesuai dengan isinya, seperti dalam merk yang sama berisi berbagai varietas dan beberapa kelas mutu beras (Suismono dan Darniadi, 2010 dalam Indrasari et al, 2016). Selain nama varietas, asal daerah penghasil beras juga sering dipalsukan. Cianjur adalah salah satu daerah yang dikenal sebagai penghasil beras bermutu tinggi. Oleh karena itu, di pasaran banyak dijumpai beras yang diberi label nama daerah ini, padahal beras yang dikemas tersebut berasal dari daerah lain.

Menghadapi fakta tersebut, kajian lebih mendalam terhadap padi varietas Pandanwangi menjadi penting untuk dilakukan. Sebagai varietas beras khusus, perlindungan terhadap keberlanjutan produksi dan keaslian padi Pandanwangi harus terus diupayakan. Kajian lebih komprehensif terkait sistem agribisnis padi Pandanwangi, termasuk kekuatan dan kelemahannya perlu pula dipelajari.

\section{METODE PENELITIAN}

Penelitian dilaksanakan di Kabupaten Cianjur, khususnya di sentra-sentra produksi padi Pandanwangi di Kecamatan Warungkondang, Cibeber, Cugenang, Gekbrong, Cilaku, dan Campaka. Lokasi ini dipilih karena secara sosial, ekonomi dan ekologis, lokasi ini memiliki karakteristik yang dapat menggambarkan sistem agribisnis padi pandanwangi secara umum. Sementara itu, data dikumpulkan melalui sejumlah cara, diantaranya melalui wawancara dengan penggunaan panduan wawancara, pelaksanaan diskusi kelompok terfokus (FGD), observasi/pengamatan dan pengumpulan data sekunder. Penggunaan teknik studi kasus dalam penelitian ini dimaksudkan untuk memfasilitasi pengamatan (observasi) dan pendeskripsian yang cermat terhadap variabel-variabel yang diteliti.

Upaya menstrukturisasi informasi, dilakukan dengan menerapkan pendekatan Soft System Metodology (SSM). SSM adalah alat penelitian ilmu sosial yang digunakan untuk menentukan permasalahan secara logis, rinci dan sistematis, dalam rangka mengambil tindakan untuk perbaikan. Melalui SSM proses pembelajaran terstruktur memungkinkan para pemangku kepentingan untuk lebih memahami situasi dan struktur masalah, potensi untuk berkembang, menyepakati rencana aksi untuk perbaikan, dan terlibat untuk perubahan atau inovasi (Checkland dan Scholes, 1990). Dalam prakteknya SSM mengidentifikasi siapa yang akan melakukan apa dan bagaimana, akan menambah orientasi aksi perspektif saran untuk memperbaiki masalah. Untuk memperbaiki masalah biasanya SSM memanfaatkan rich picture, CATWOE, dan analisis 1, 2 dan 3 dari para pemangku keputusan (Georgio, 2008). Bahkan Wilson dan Morren (1990), Kunsh et al (2009), Mingers (2011) menambahkan bahwa SSM memungkinkan pemecahan 
masalah melalui dialog, dan metode kualitatif, yang secara ekplisit mempertimbangkan aspek etika, keberlanjutan dan nilai-nilai kemanusiaan (Alamsyah, 2011).

Tujuh tahap dari model SSM digunakan untuk kajian interaksi pelaku. Tujuh tahap tersebut merupakan sejumlah ilustrasi yang disuling dari suatu proses iteratif sehingga dalam prakteknya, proses dapat dimulai dari mana saja. Ketujuh tahap tersebut menurut Checkland \& Scholes (1990) dalam Alamsyah (2011) adalah: (1) mengkaji masalah yang tidak terstruktur; (2) mengekspresikan situasi masalah; (3) membangun definisi masalah yang berkaitan dengan situasi masalah; (4) membangun model konseptual; (5) membandingkan model konseptual dengan situasi masalah; (6) menetapkan perubahan yang layak dan diinginkan; dan (7) melakukan tindakan perbaikan atas masalah (lihat Gambar 1).

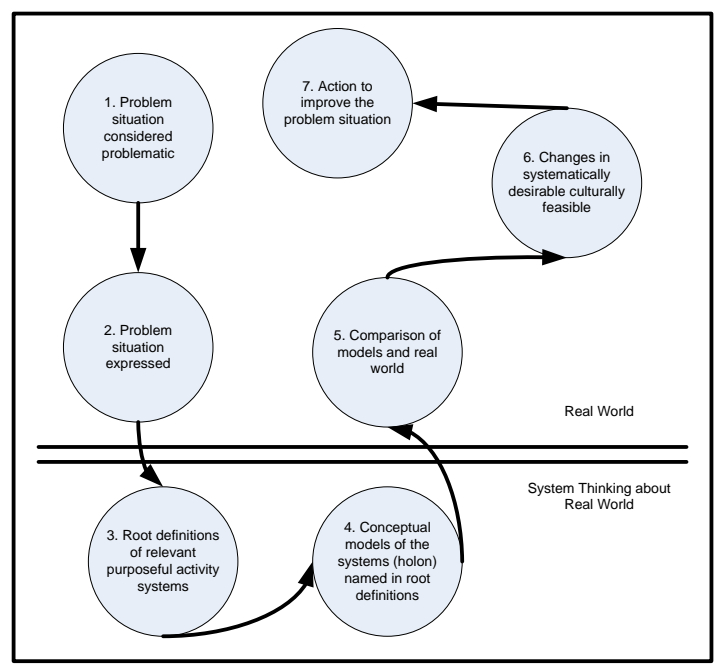

Gambar 1. Tahapan SSM

\section{HASIL DAN PEMBAHASAN}

Padi pandanwangi Cianjur merupakan jenis padi aromatik yang tergolong padi bulu (Javonica). Selain beraroma pandan, uniknya padi pandawangi Cianjur dipanen dan disimpan dalam bentuk malai. Padi pandanwangi cocok tumbuh pada suhu 25 ${ }^{\circ} \mathrm{C}$ hingga $30{ }^{\circ} \mathrm{C}$, dengan ketinggian 450 -
800 mdpl. Gabah padi pandanwangi

Cianjur berbentuk bulat agak panjang, warna kuning emas, bulunya menyerupai keris dan harum pandan.

Secara administratif, kawasan sentra produksi padi pandanwangi terdiri atas tujuh kecamatan. Gambaran singkat dari kecamatan-kecamatan tersebut dapat dilihat pada Tabel 2. berikut:

Tabel 2. Sentra Produksi Padi Pandanwangi Kabupaten Cianjur

\begin{tabular}{|c|c|c|c|c|}
\hline $\begin{array}{l}\text { Keca } \\
\text { matan }\end{array}$ & $\begin{array}{l}\text { Jum } \\
\text { lah } \\
\text { Desa }\end{array}$ & $\begin{array}{c}\text { Luas } \\
\text { Sawah } \\
(\mathrm{Ha})\end{array}$ & $\begin{array}{c}\text { Jenis } \\
\text { Tanah }\end{array}$ & $\begin{array}{l}\text { Keting } \\
\text { gian } \\
\text { Tempat } \\
\text { (mdpl) }\end{array}$ \\
\hline $\begin{array}{l}\text { Warung } \\
\text { kondang }\end{array}$ & 11 & 1.644 & $\begin{array}{l}\text { Latosol, } \\
\text { Andosol }\end{array}$ & $300-900$ \\
\hline Cianjur & 11 & 1.047 & Latosol & $436-675$ \\
\hline Cilaku & 12 & 2.570 & Latosol & 436-675 \\
\hline Cibeber & 18 & 3.198 & $\begin{array}{l}\text { Latosol, } \\
\text { Posdolik }\end{array}$ & $200-1.250$ \\
\hline Cugenang & 16 & 3.174 & $\begin{array}{l}\text { Latosol, } \\
\text { Andosol }\end{array}$ & $300-1.035$ \\
\hline Campaka & & 1.432 & Podsolik & $470-700$ \\
\hline Gekbrong & 8 & 891 & Latosol & $300-900$ \\
\hline
\end{tabular}

\section{Pendekatan Soft System Methodology dalam Sistem Agribisnis Padi Pandanwangi Cianjur}

\section{Problem Situation}

\section{a. Kondisi Ideal}

Secara keseluruhan, berbagai stakeholder dalam kawasan budidaya dan pengembangan padi pandanwangi Cianjur menyatakan bahwa pelestarian padi pandanwangi sebagai plasma nutfah asli Cianjur harus dilakukan. Secara spesifik, kondisi ideal tersebut dinyatakan sebagai berikut:

- Komoditi spesifik padi pandanwangi harus tetap dilestarikan agar tetap eksis sebagai komoditi unggulan Kabupaten Cianjur, karena terbukti memiliki keunggulan komparatif dan kompetitif yang dapat meningkatkan pendapatan, 
kesejahteraan, dan pengentasan kemiskinan.

- Program pengembangan agroindutri dan pemasaran beras pandanwangi berlabel seyogyanya dijadikan Program Pengembangan Pertanian di Kabupaten Cianjur, terus dilaksanakan pembinaan dan pendampingan sehingga dapat meningkatkan pendapatan asli daerah Kabupaten Cianjur.

- Suatu lembaga yang mengawasi kualitas beras Pandanwangi di pasaran, terutama dalam kemasan berlabel, agar tidak merugikan konsumen, petani, serta para pengusaha pemasaran beras harus dapat bekerja dengan efektif.

- Petani selayaknya adalah sebagai inti atau unit agribisnis terkecil juga sebagai pelaku produksi serta manajer usahatani yang perlu didorong berperan besar dan mempunyai kebebasan dalam menentukan masa depan bisnis pertaniannya.

- Harus dipertahankan fungsi dan peran pemerintah untuk tetap sebagai fasilitator dengan menekankan kebijakan dan memanfaatkan kewenangan yang dimiliki untuk mendorong petani menyelenggarakan bisnis padi pandanwangi.

\section{b. Kondisi Nyata}

Kompleksitas persoalan yang dihadapi oleh padi pandanwangi dan lemahnya kolaborasi antar pelaku di sepanjang rantai nilai, berdampak pada tidak optimalnya proses bisnis dalam pengembangan padi pandanwangi Cianjur. Berbeda dengan kondisi pada industri lain, seperti pada rantai pasok manufaktur, padi pandanwangi dikembangkan oleh sekian banyak pelaku, yang sebagian besar diantaranya adalah pelaku-pelaku dengan skala usaha kecil.

Dalam kasus pengembangan padi pandanwangi Cianjur, tidak tumbuhnya pandanwangi sebagai komoditas unggul di

Kabupaten Cianjur, dapat terjadi karena sejumlah alasan, diantaranya:

- Waktu budidaya yang lebih panjang tidak diimbangi dengan insentif harga yang memadai bagi petani. Sejumlah petani di lokasi kajian menyatakan bahwa motif mereka untuk membudidayakan padi pandanwangi lebih disebabkan oleh keinginan mereka untuk melestarikan padi pandanwangi sebagai ikon dan plasma nutfah Kabupaten Cianjur. Sebuah kajian yang dilakukan oleh BPP Gekbrong bahkan menunjukkan bahwa untuk kondisi saat kajian dilakukan (2013), usahatani padi pandanwangi menghasilkan net profit yang lebih rendah dibandingkan dengan usahatani padi VUB (Mekongga). Kondisi ini menjadi disinsentif bagi petani untuk terus membudidayakan padi pandanwangi. Tabel 2 menunjukkan perbandingan tersebut.

Tabel 2. Perbandingan Keuntungan Usahatani Padi Varietas Lokal Pandanwangi Cianjur (VLPWC) dan Padi Varietas Unggul Baru (VUB)

\begin{tabular}{|c|c|c|}
\hline Komponen & $\begin{array}{c}\text { VLPWC } \\
\text { (Rp) }\end{array}$ & VUB (Rp) \\
\hline \multicolumn{3}{|l|}{ Pengadaan } \\
\hline \multicolumn{3}{|l|}{ Saprodi } \\
\hline a. Benih & 500,000 & 200,000 \\
\hline b.Pupuk & $1,005,000$ & $1,120,000$ \\
\hline Upah Kerja & $6,625,000$ & $6,325,000$ \\
\hline $\begin{array}{l}\text { Kisaran } \\
\text { perbedaan waktu } \\
(44 \mathrm{hr})\end{array}$ & $12,160,000$ & 0 \\
\hline Jumlah & $18,685,000$ & $7,845,000$ \\
\hline Produksi/Panen & $\begin{array}{r}36,960,000 \\
(8800 \times \mathrm{Rp} \\
4200)\end{array}$ & $\begin{array}{r}30,400,000 \\
(8000 \mathrm{~kg} \mathrm{x} \\
\text { Rp 3800) }\end{array}$ \\
\hline Net Profit & $18,275,000$ & $22,555,000$ \\
\hline \multicolumn{3}{|c|}{ Sumber: BPP Gekbrong (2013) } \\
\hline \multicolumn{3}{|c|}{$\begin{array}{l}\text { - Terjadi sejumlah pemalsuan beras } \\
\text { pandanwangi dengan berbagai jenisnya, } \\
\text { berakibat pada makin menurunnya minat } \\
\text { petani untuk membudidayakan padi } \\
\text { pandanwangi Cianjur. }\end{array}$} \\
\hline $\begin{array}{l}\text { Fungsi kelemb } \\
\text { Pelestari Padi P }\end{array}$ & $\begin{array}{l}\text { n Masy: } \\
\text { nwangi }\end{array}$ & at \\
\hline
\end{tabular}


(MP3C) sebagai entitas yang memiliki kewenangan untuk mengontrol kualitas padi dan beras pandanwangi Cianjur di pasar, belum sepenuhnya berjalan dengan optimal. Hingga saat ini MP3C belum mampu secara efektif memastikan kualitas padi dan beras, serta sistem yang transparan dan berkeadilan bagi seluruh pelaku usaha padi pandanwangi Cianjur.

- Berbagai upaya pelestarian padi pandanwangi yang diinisiasi oleh pemerintah daerah belum mampu mengangkat posisi dan kondisi pengembangan padi pandanwangi. Keberadaan Kampung Budaya Pandanwangi diharapkan dapat memperbaiki posisi dan kondisi tersebut. Namun demikian, pengembangan kampung budaya ini hingga saat ini pun masih dalam proses pembangunan dan nampaknya belum akan mampu dengan cepat memperbaiki kondisi ini

- Di sejumlah kecamatan, sebagian besar petani adalah petani penggarap, sehingga faktor pemilik lahan sangat menentukan teknis budidaya, selain itu penguasaan lahannya umumnya juga sempit. Jika dilaksanakan melalui corporate farming juga tidak mudah, sekali lagi karena faktor pemilik lahan. Secara spesifik di Desa Jambudipa Kecamatan Warungkondang, yang adalah salah satu sentra utama pengembangan padi pandanwangi, petani merasa kesulitan dalam mengambil keputusan akibat status kepemilikan lahannya ini. Kondisi ini juga pada dasarnya terjadi di seluruh Kawasan pengembangan padi pandanwangi di Kabupaten Cianjur.

- Satu faktor lagi yang harus mendapat perhatian adalah program pemerintah daerah belum sepenuhnya secara masif dan bersama-sama mendorong pengembangan padi pandanwangi Cianjur. Berbagai program telah dilakukan, namun persoalan klasik koordinasi terkait siapa mengerjakan apa, siapa bertanggung jawab atas apa, masih tetap terjadi, dan pada akhirnya mensubordinasi berbagai upaya yang telah dilaksanakan.

\section{Rich Picture}

Rich picture bertujuan untuk memahami situasi masalah dari berbagai perspektif, dan menekankan struktur, proses, hubungan, konflik dan ketidakpastian, serta mengungkapkan keprihatinan, nilainilai yang diyakini, kemudian memvisualisasikan aspek abstrak tersebut melalui simbol-simbol.

Para pemangku kepentingan yang terkait pada pengembangan padi pandanwangi adalah para petani, pengumpul dan pengolah padi, pedagang beras, penyuluh pertanian, dinas pertanian tanaman pangan Kabupaten Cianjur, kelompok pengembang pariwisata (kompepar), karang taruna/pemuda tani (lihat Gambar 2)

\section{Analisis Budaya}

Analisis budaya memandang intervensi itu sendiri sebagai masalah dan mengidentifikasi: 1) intervensi struktur dan peran (analisis 1), 2) hubungan antara peran, nilai dan norma (analisis 2), serta 3) dimensi politik (analisis 3) (Checkland dan Scholes 1990, 45-51).

\section{a. Intervensi Struktur dan Peran}

Struktur dan peran dapat digambarkan dalam Tabel 3 berikut.

Tabel 3. Aspek dan Uraian Intervensi Struktur dan Peran

\begin{tabular}{ll}
\hline \multicolumn{1}{c}{ Aspek } & \multicolumn{1}{c}{ Uraian } \\
\hline Klien: Sejumlah & Petani, pengepul dan \\
pihak terkait & pengolah padi, pedagang \\
pengembangan & beras, penyuluh \\
padi & pertanian, Dinas \\
pandanwangi & Pertanian Tanaman \\
& Pangan Kabupaten \\
& Cianjur, karang \\
& taruna/pemuda tani, \\
& kelompok pengembang
\end{tabular}




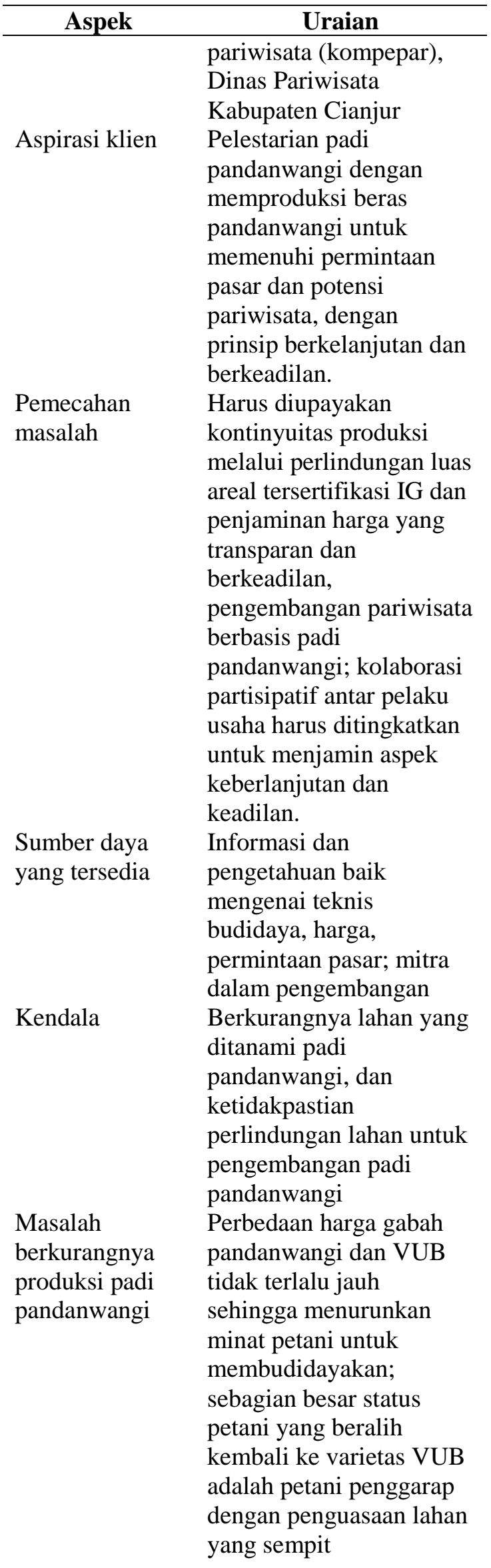

\begin{tabular}{ll}
\hline \multicolumn{1}{c}{ Aspek } & \multicolumn{1}{c}{ Uraian } \\
\hline Implikasi dari & Jika perbedaan harga \\
dipilih yang & gabah pandanwangi dan \\
& VUB lebih tinggi, dapat \\
& meningkatkan minat \\
& petani untuk berusahatani \\
& padi pandanwangi; jika \\
& pemilik lahan dapat \\
& didorong untuk \\
& mengusahakan padi \\
& pandanwangi, dapat \\
& meningkatkan produksi \\
& padi pandanwangi untuk \\
& memenuhi peluang pasar \\
& dan pariwisata. \\
& Berkurangnya potensi \\
& lahan produktif untuk \\
& memenuhi permintaan \\
Alasan & pasar dan pariwisata; \\
menentukan & Kehilangan peluang \\
masalah & pasar; Kurangnya \\
& koordinasi dan kolaborasi \\
& yang efektif antar \\
& pemangku keputusan, \\
& terutama petani (termasuk \\
& para pemilik lahan). \\
& Transparansi dan \\
& keadilan bagi seluruh \\
& pelaku pengembangan \\
& (misalnya dalam \\
& penetapan harga) dapat \\
& menjamin keberlanjutan \\
& produksi; meningkatkan \\
& kolaborasi antar pelaku \\
& pengembangan padi \\
& pandanwangi, termasuk \\
& pemilik lahan yang \\
& memiliki kekuatan \\
permasalahan & memaksa para penggarap \\
& lahan. \\
\hline Nilai positif & \\
& \\
&
\end{tabular}




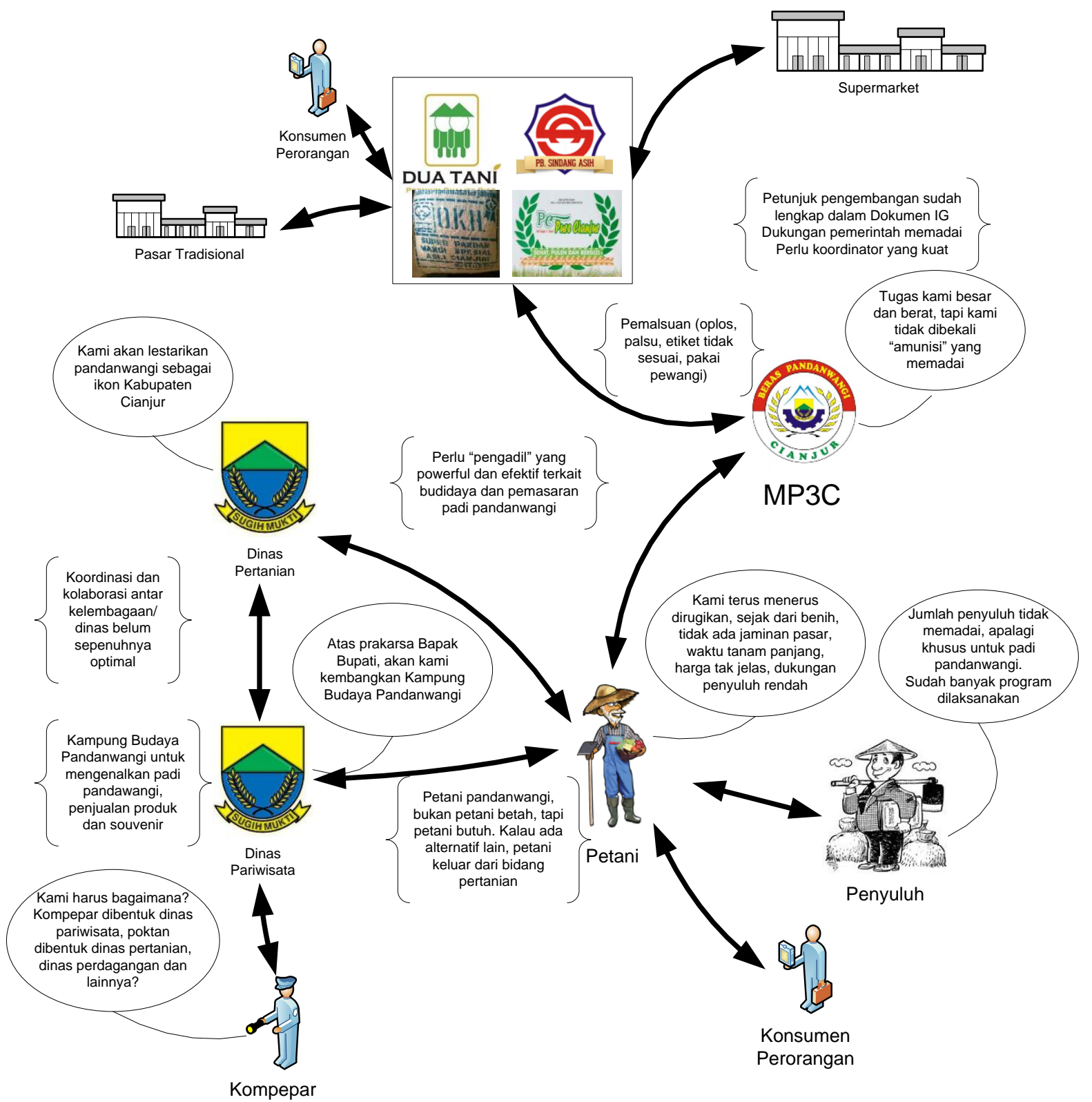

Gambar 2. Rich Picture Padi Pandanwangi Cianjur 


\section{b. Hubungan antara Peran, Nilai, dan Norma}

Sebagai bentuk budidaya padi yang menjunjung tinggi aspek budaya, lingkungan, keadilan dan keberlanjutan, pengembangan padi pandanwangi telah menjadi energi pendorong bagi petani untuk melestarikan kekayaan plasma nutfah lokal bagi petani di Kabupaten Cianjur. Berbagai program yang diinisiasi oleh sejumlah kelembagaan dan dinas di Kabupaten Cianjur atas prakarsa Bupati Cianjur menjadi pendorong tambahan lainnya. Semangat petani untuk membudidayakan padi pandanwangi, meskipun dihadapkan pada rendahnya penghargaan dan insentif budidaya (harga) dapat menjadi awal langkah petani pandanwangi melestarikan plasma nutfah ini.

Namun demikian, karena sejumlah alasan seperti kepemilikan lahan yang sempit bahkan status sebagai petani penggarap, lama waktu budidaya padi pandanwangi, serta perbedaan harga gabah yang tidak terlalu jauh, sejak awal tahun 2000an banyak petani di tujuh kecamatan tersertifikasi indikasi geografis, mulai mengubah kebiasaan budidaya atau bertani padi pandanwangi kepada bertani padi VUB. Hal ini menyebabkan berkurangnya lahan pertanian yang membudidayakan padi pandanwangi dan menurunkan produksi padi pandanwangi untuk memenuhi pasar dan potensi pariwisata. Kurang terkoordinasinya berbagai dinas dan kelembagaan pemerintah dalam melaksanakan program pengembangan juga telah secara kontraproduktif menurunkan minat petani untuk berusaha tani padi pandanwangi. Dalam keadaan ini nampak bahwa tidak terjadi keselarasan antara peran yang seharusnya dijalankan oleh seluruh pelaku dengan nilai dan norma yang sebelumnya sudah disepakati untuk secara bersama-sama mengupayakan tercapainya tujuan pembudidayaan padi pandanwangi ini.

\section{c. Dimensi Politik}

Mitra petani terdiri atas gapoktan, pengepul dan pengolah padi, pedagang beras, Dinas Pertanian Tanaman Pangan Kab. Cianjur, serta pengurus MP3C. Mitra petani yang memiliki power untuk mengubah atau menentukan perubahan adalah pengolah padi (pedagang beras), MP3C, dan Dinas Pertanian Tanaman Pangan Kab. Cianjur.

- Sebagai pihak yang memasarkan produk beras pandanwangi, saat ini terdapat empat perusahaan yang secara resmi memperoleh ijin pemasaran padi pandanwangi dari MP3C, yaitu:

Sindang Asih, OKH, Pure Cianjur, dan Wahana Inti Makmur. Keempat perusahaan ini dapat menentukan harga beras pandanwangi secara tidak langsung sampai pada tingkat petani.

- Dinas Pertanian Tanaman Pangan Kab. Cianjur memiliki kemampuan untuk menentukan regulasi dan kebijakan yang harus dijalankan oleh seluruh pelaku hingga berpengaruh sampai tingkat petani. Koordinasi antar level dan antar bagian pemerintah juga harus ditingkatkan, sehingga satu sama lain saling mendukung dan tidak saling mengsubordinasi.

- MP3C memiliki power untuk mengubah perilaku budidaya dan pemasaran dengan mensyaratkan sertifikasi padi pandanwangi berdasarkan standar mereka, termasuk di dalamnya adalah melakukan kontrol terhadap proses budidaya dan pemasaran berikutnya.

- Pemilik lahan yang tidak perduli terhadap proses produksi padi pandanwangi juga memiliki power untuk menentukan teknis budidaya dan pemilihan varietas. 


\section{Definition of Relevant System (CATWOE)}

\section{a. Formulasi Transformasi (T)}

$\mathrm{T}$ : meningkatkan lahan pembudidayaan padi pandanwangi, dengan menjunjung asas transparansi dan keadilan.

\section{b. CATWOE berdasarkan Transformasi}

a) C: Customer (pelanggan-korban atau penerima manfaat): pelaku pasar (pedagang padi pandanwangi), Dinas Pertanian Tanaman Pangan Kabupaten Cianjur

b) A: Actor (aktor yang melakukan transformasi): petani

c) T: Transformation (perubahan): meningkatkan lahan pembudidayaan padi pandanwangi, dengan menjunjung asas transparansi dan keadilan.

d) W: Weltanschauung-perspektif bermakna: budidaya padi pandanwangi sesuai standar, produksi dan pemasaran padi pandanwangi disertifikasi oleh MP3C.

e) O: Owner (pihak yang mungkin menghentikan Transformasi): petani, Dinas Pertanian Tanaman Pangan Kabupaten Cianjur.

f) E: Environment (kendala lingkungan): budaya dan sikap menjadi kendala lingkungan yang mengakibatkan sejumlah petani tidak lagi budidaya padi pandanwangi.

\section{c. Root Definition}

Luas lahan budidaya padi pandanwangi meningkat untuk memenuhi permintaan pasar dan peluang pariwisata dari pengembangan Kampung Budaya Pandanwangi. Sertifikasi produk pandanwangi oleh MP3C harus menjamin dipenuhinya asas transparansi dan keadilan. MP3C dibentuk untuk melakukan sistem kontrol, berkoordinasi dengan petani dan pedagang, sehingga budidaya dan pemasaran padi pandanwangi sesuai standar dan lulus uji sertifikasi padi pandanwangi berdasarkan sertifikat IG.

\section{Modeling Relevant System}

\section{a. Formulasi "5 E"}

Tabel 4. Formulasi "5E"

\begin{tabular}{|c|c|}
\hline Aspek & Formulasi \\
\hline Efficacy & $\begin{array}{l}\text { transparansi dan kolaborasi } \\
\text { dalam seluruh proses } \\
\text { agribisnis padi pandanwangi }\end{array}$ \\
\hline Efficiency & $\begin{array}{l}\text { sumber daya yang digunakan } \\
\text { sesuai dengan prinsip } \\
\text { budidaya padi pandanwangi } \\
\text { menurut sertifikasi IG }\end{array}$ \\
\hline Effectiveness & $\begin{array}{l}\text { persiapan pembudidayaan } \\
\text { dilaksanakan optimal dan } \\
\text { terpadu untuk menjamin } \\
\text { tercapainya produksi }\end{array}$ \\
\hline Ethicality & $\begin{array}{l}\text { proses pembudidayaan padi } \\
\text { pandanwangi tidak } \\
\text { mengurangi hak petani untuk } \\
\text { menentukan usaha taninya } \\
\text { sendiri }\end{array}$ \\
\hline Elegance & $\begin{array}{l}\text { seluruh proses } \\
\text { pembudidayaan dilakukan } \\
\text { dengan mempertimbangkan } \\
\text { asas keberlanjutan untuk } \\
\text { mewujudkan transformasi }\end{array}$ \\
\hline
\end{tabular}

\section{b. Human Activity System}

Dalam kajian ini Human activity system (HAS) menunjukkan keterkaitan aktivitas pelaku pengembangan padi pandanwangi yang diperlukan untuk mewujudkan transformasi, yaitu mempertahankan dan meningkatkan produksi padi pandanwangi, dengan menjunjung asas transparansi dan keadilan. 


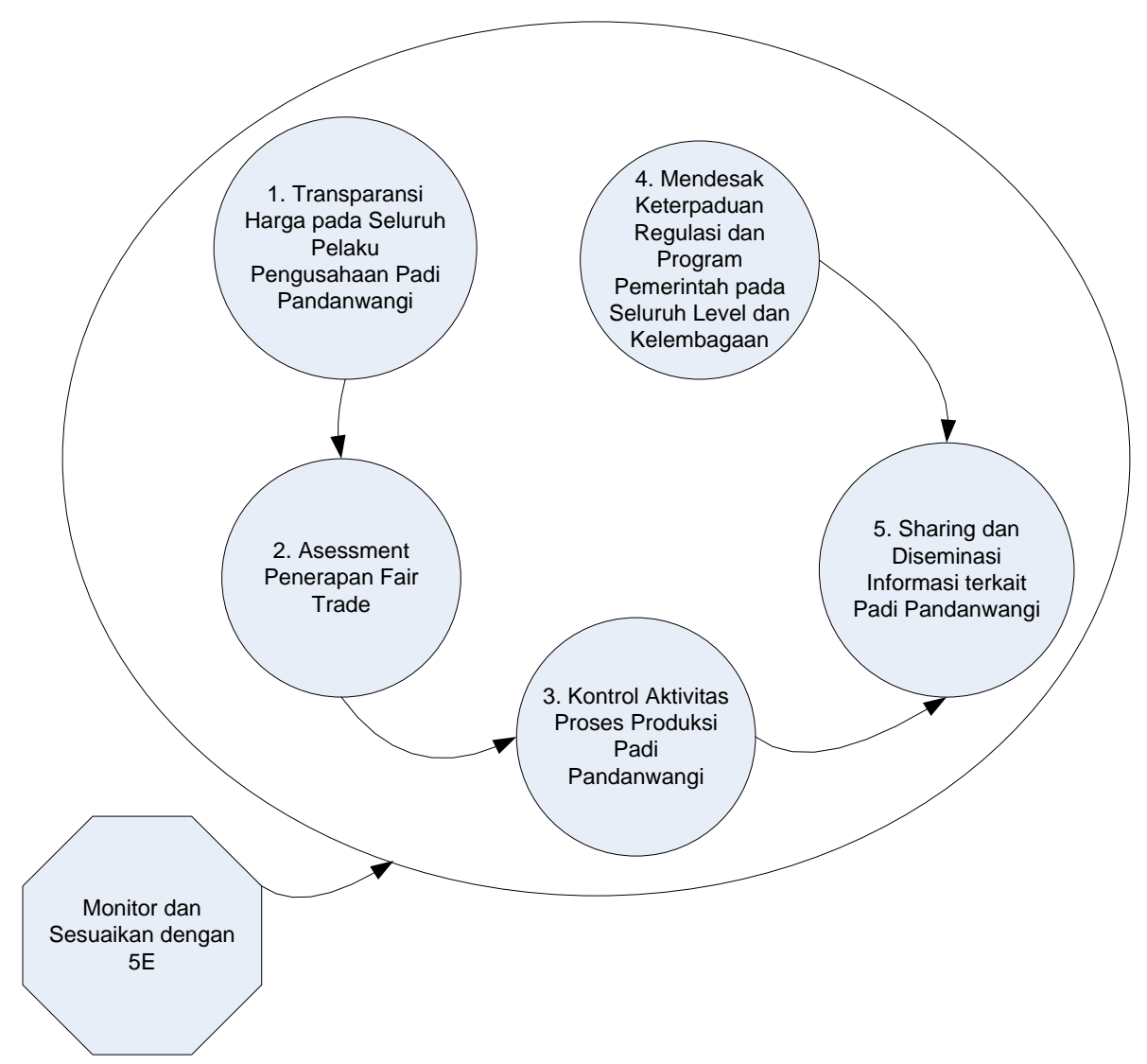

Gambar 3. Human Activity System Padi Pandanwangi Cianjur

\section{Perbandingan Model dengan Dunia Nyata}

Pemangku kepentingan membandingkan model konseptual (Human Activity System) dengan dunia nyata melalui sejumlah pertanyaan sebagaimana dapat dilihat pada Tabel 5.

Tabel 5. Perbandingan Model dengan Dunia Nyata

\begin{tabular}{|c|c|c|c|c|c|}
\hline $\begin{array}{c}\text { Aktivitas pada } \\
\text { Model }\end{array}$ & $\begin{array}{c}\text { Ada/ } \\
\text { Tidak? }\end{array}$ & Bagaimana? & Siapa? & $\begin{array}{l}\text { Baik/ } \\
\text { Buruk? }\end{array}$ & Alternatif \\
\hline $\begin{array}{l}\text { Transparansi } \\
\text { Harga pada } \\
\text { Seluruh Pelaku } \\
\text { Pengusahaan } \\
\text { Padi } \\
\text { Pandanwangi }\end{array}$ & Tidak & $\begin{array}{l}\text { Petani tidak } \\
\text { pernah tahu } \\
\text { proses berikutnya } \\
\text { dari gabah yang } \\
\text { sudah mereka jual }\end{array}$ & $\begin{array}{l}\text { Pengepul/pedagang } \\
\text { beras, Kelompok } \\
\text { tani, Petani, MP3C }\end{array}$ & Baik & $\begin{array}{l}\text { Harga } \\
\text { transparan sejak } \\
\text { dari harga } \\
\text { pedagang } \\
\text { hingga petani } \\
\text { untuk menjaga } \\
\text { keadilan dan } \\
\text { keberlanjutan }\end{array}$ \\
\hline $\begin{array}{l}\text { Asessment } \\
\text { Penerapan Fair } \\
\text { Trade }\end{array}$ & Tidak & $\begin{array}{l}\text { Penilaian terhadap } \\
4 \text { prinsip fair } \\
\text { trade: lingkungan, } \\
\text { pekerja, ekonomi, } \\
\text { sosial }\end{array}$ & $\begin{array}{l}\text { Petani, pedagang } \\
\text { beras, MP3C }\end{array}$ & Baik & $\begin{array}{l}\text { Pengajuan } \\
\text { penilaian skim } \\
\text { fair trade }\end{array}$ \\
\hline $\begin{array}{l}\text { Kontrol } \\
\text { Aktivitas Proses }\end{array}$ & Ada & $\begin{array}{l}\text { MP3C } \\
\text { memastikan } \\
\text { proses produksi }\end{array}$ & $\begin{array}{l}\text { Kelompok tani, } \\
\text { MP3C }\end{array}$ & Baik & - \\
\hline
\end{tabular}




\begin{tabular}{|c|c|c|c|c|c|}
\hline $\begin{array}{c}\text { Aktivitas pada } \\
\text { Model }\end{array}$ & $\begin{array}{c}\text { Ada/ } \\
\text { Tidak? }\end{array}$ & Bagaimana? & Siapa? & $\begin{array}{l}\text { Baik/ } \\
\text { Buruk? }\end{array}$ & Alternatif \\
\hline $\begin{array}{l}\text { Produksi Padi } \\
\text { Pandanwangi }\end{array}$ & & $\begin{array}{l}\text { memenuhi } \\
\text { persyaratan } \\
\text { budidaya padi } \\
\text { pandanwangi } \\
\text { sesuai standar IG }\end{array}$ & & & \\
\hline $\begin{array}{l}\text { Mendesak } \\
\text { Keterpaduan } \\
\text { Regulasi dan } \\
\text { Program } \\
\text { Pemerintah } \\
\text { pada Seluruh } \\
\text { Level dan } \\
\text { Kelembagaan }\end{array}$ & Tidak & $\begin{array}{l}\text { Regulasi } \\
\text { pemerintah pada } \\
\text { seluruh tingkatan } \\
\text { harus memastikan } \\
\text { dukungan yang } \\
\text { sejalan dengan } \\
\text { pengembangan } \\
\text { padi pandanwangi }\end{array}$ & $\begin{array}{l}\text { Kelompok tani, } \\
\text { Pemerintah } \\
\text { (daerah), MP3C }\end{array}$ & Baik & - \\
\hline $\begin{array}{l}\text { Sharing dan } \\
\text { Diseminasi } \\
\text { Informasi } \\
\text { terkait Padi } \\
\text { Pandanwangi }\end{array}$ & Tidak & $\begin{array}{l}\text { Tidak terdapat } \\
\text { pertemuan rutin } \\
\text { petani dengan } \\
\text { pihak terkait } \\
\text { lainnya }\end{array}$ & $\begin{array}{l}\text { Petani, kelompok } \\
\text { tani, MP3C, } \\
\text { Pemerintah (daerah) }\end{array}$ & Baik & $\begin{array}{l}\text { Penggunaan } \\
\text { teknologi } \\
\text { (telpon } \\
\text { genggam } \\
\text { misalnya) }\end{array}$ \\
\hline
\end{tabular}

\section{Perumusan Perubahan}

Sebagai hasil dari tahap HAS yang dibandingkan dengan keadaan dunia nyata, pemangku kepentingan kemudian merumuskan perubahan yang diinginkan secara sistematis dan secara kultural layak, relevan, bermakna, dan memenuhi kebutuhan serta keinginan pemangku kepentingan (Checkland 2001: 85-86). Rumusan perubahan tersebut disusun dengan menjawab pertanyaan-pertanyaan pada tabel 6 berikut.

\section{Tabel 6. Rumusan Perubahan Proses SSM}

\begin{tabular}{|c|c|c|c|}
\hline Kegiatan & Diperlukan? & $\begin{array}{c}\text { Dapat } \\
\text { Dilakukan? }\end{array}$ & Kemungkinan Aksi Nyata \\
\hline $\begin{array}{l}\text { Transparansi Harga } \\
\text { pada Seluruh Pelaku } \\
\text { Pengusahaan Padi } \\
\text { Pandanwangi }\end{array}$ & Ya & Dapat & $\begin{array}{l}\text { Kolaborasi antara pedagang, dan petani } \\
\text { dioptimalkan, meminta pedagang untuk } \\
\text { mendiskusikan nilai harga belinya } \\
\text { (transparent margin) untuk menjaga } \\
\text { keadilan dan keberlanjutan }\end{array}$ \\
\hline $\begin{array}{l}\text { Asessment Penerapan } \\
\text { Fair Trade }\end{array}$ & Ya & Dapat & $\begin{array}{l}\text { Optimalisasi peran MP3C, meningkatkan } \\
\text { insentif MP3C, menentukan dan } \\
\text { melaksanakan indikator nyata yang terukur } \\
\text { terhadap pencapaian } 4 \text { aspek fair trade }\end{array}$ \\
\hline $\begin{array}{l}\text { Kontrol Aktivitas } \\
\text { Proses Produksi Padi } \\
\text { Pandanwangi }\end{array}$ & Ya & Dapat & $\begin{array}{l}\text { Melibatkan petani dan kelompok tani } \\
\text { secara lebih aktif, mengangkat anggota } \\
\text { kelompok tani sebagai mitra MP3C, } \\
\text { mengoptimalkan peran MP3C }\end{array}$ \\
\hline $\begin{array}{l}\text { Mendesak } \\
\text { Keterpaduan Regulasi } \\
\text { dan Program } \\
\text { Pemerintah pada } \\
\text { Seluruh Level dan } \\
\text { Kelembagaan }\end{array}$ & Ya & Dapat & $\begin{array}{l}\text { Konsultasi dan audiensi berkala dari } \\
\text { kelompok tani kepada pemerintah (daerah) } \\
\text { terkait perkembangan usaha tani padi } \\
\text { pandanwangi dan menyampaikan } \\
\text { kebutuhan dari sisi kebijakan. Sebaliknya, } \\
\text { pemerintah juga diharapkan berperan } \\
\text { secara proaktif }\end{array}$ \\
\hline
\end{tabular}




\begin{tabular}{|c|c|c|c|}
\hline Kegiatan & Diperlukan? & $\begin{array}{c}\text { Dapat } \\
\text { Dilakukan? }\end{array}$ & Kemungkinan Aksi Nyata \\
\hline $\begin{array}{l}\text { Sharing dan } \\
\text { Diseminasi Informasi } \\
\text { terkait Padi } \\
\text { Pandanwangi }\end{array}$ & Ya & Dapat & $\begin{array}{l}\text { Optimalisasi pertemuan berkala petani } \\
\text { dengan kelompok tani. Meminta sejumlah } \\
\text { petani berprestasi untuk melakukan } \\
\text { diseminasi berkeliling kepada seluruh } \\
\text { kelompok tani di seluruh kecamatan ber IG } \\
\text { di Cianjur }\end{array}$ \\
\hline
\end{tabular}

\section{PengambilanTindakan}

Pengambilan tindakan dilakukan pada tahap terakhir setelah melaksanakan analisis: 1) rich picture, 2) analisis budaya (analisis 1, 2, dan 3) dari para pemangku keputusan, 3) definisi sistem relevan menggunakan CATWOE, 4) sistem pemodelan relevan menggunakan konsep Human Activity System (HAS), 5) perbandingan model konseptual dengan dunia nyata, dan 6) perumusan perbaikan. Tahap terakhir pengambilan tindakan sepenuhnya diserahkan kepada para pemangku kepentingan sebagai pelaku pengembangan padi pandanwangi. Perbaikan tindakan direkomendasikan untuk dilaksanakan sebelum proses produksi berikutnya, agar terdapat waktu yang memadai untuk melakukan implementasi konsep perbaikan yang direkomendasikan.

\section{SIMPULAN DAN REKOMENDASI}

Pengembangan padi pandanwangi sebagai upaya pelestarian plasma nutfah Cianjur telah, sedang dan terlihat akan terus diupayakan oleh pemerintah dan warga masyarakat Cianjur. Berbagai permasalahan yang teridentifikasi menunjukkan perlunya evaluasi terhadap tingkat efektivitas keberhasilan berbagai upaya tadi. Sejumlah langkah yang mengaitkan aspek di luar finansial dan ekonomi, seperti aspek pariwisata misalnya, memberikan harapan dan potensi keberhasilan pengembangan padi pandanwangi di masa depan.

Tindakan strategis sebagaimana diuraikan dalam langkah perumusan perubahan dalam paper ini dapat dilakukan dengan cara langkah demi langkah, dilakukan dengan monitoring yang terarah, dan sebaiknya dikoordinasi oleh sebuah kelembagaan yang dibentuk dan ditugaskan secara khusus.

\section{DAFTAR PUSTAKA}

Alamsyah, Purnama dan Iin Surminah. 2011. Ilustrasi Penggunaan Soft System Methodology dalam Memahami Kemitraan antara Lembaga Litbang Pemerintah dengan Industri. Warta Kebijakan Iptek dan Manajemen Litbang. LIPI. Jakarta

Indrasari, Siti Dewi, Purwaningsih, Erni Apriyati, dan Shinta Dewi Ardhiyanti. 2016. Preferensi Konsumen pada Beras Berlabel Jaminan Varietas untuk Hipa 8 , Ciherang dan Inpari 13. Jurnal Penelitian Pertanian Tanaman Pangan Vol. 35 No. 3

Kerlinger, F.N. 1990. Asas-asas Penelitian Behavioral. Edisi Ketiga. Simatupang LR, Penerjemah. Gadjah Mada Press. Yogyakarta.

Maqsood, Tayyab., Finegan, Andrew D., \& Walker, Derek H. 2001. Five case studies applying soft system methodology to knowledge management. In conference's name unknown. http://eprints.qut.edu.au/27456.

MP3C. (Masyarakat Pelestari Padi Pandanwangi Cianjur). 2015. Buku Persyaratan Permohonan 
Pendaftaran Perlindungan Indikasi Geografis Beras Pandanwangi

Cianjur. Cianjur

Podesta, Rosana. 2009. Pengaruh Penggunaan Benih Sertifikat terhadap Efisiensi dan Pendapatan Usahatani Padi Pandanwangi. Skripsi Departemen FEM IPB.

Bogor
Ricardo, David. 1971 (1817). The Principles of Political Economic and Taxaxion. Baltimore, Penguin.

Sevilla, Consuelo G. et. al (2007). Research Methods. Rex Printing Company. Quezon City. 